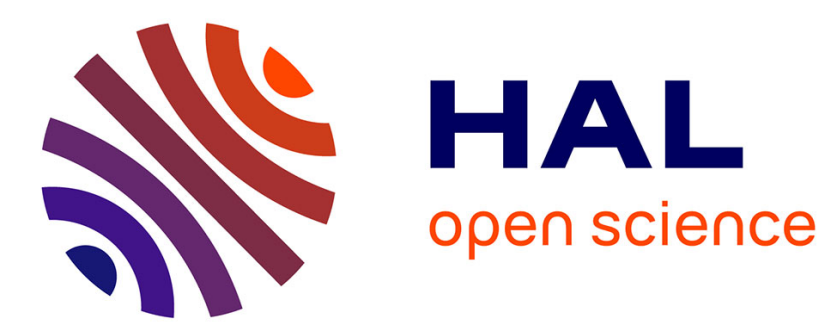

\title{
Designing Proactive Business Event Services
}

\author{
Helena Kõrge, Regina Erlenheim, Dirk Draheim
}

\section{To cite this version:}

Helena Kõrge, Regina Erlenheim, Dirk Draheim. Designing Proactive Business Event Services. 11th International Conference on Electronic Participation (ePart), Sep 2019, San Benedetto Del Tronto, Italy. pp.73-84, 10.1007/978-3-030-27397-2_7 . hal-02446020

\section{HAL Id: hal-02446020 \\ https://hal.inria.fr/hal-02446020}

Submitted on 20 Jan 2020

HAL is a multi-disciplinary open access archive for the deposit and dissemination of scientific research documents, whether they are published or not. The documents may come from teaching and research institutions in France or abroad, or from public or private research centers.
L'archive ouverte pluridisciplinaire HAL, est destinée au dépôt et à la diffusion de documents scientifiques de niveau recherche, publiés ou non, émanant des établissements d'enseignement et de recherche français ou étrangers, des laboratoires publics ou privés. 


\title{
Designing Proactive Business Event Services A Case Study of the Estonian Company Registration Portal
}

\author{
Helena Kõrge ${ }^{1}$, Regina Erlenheim ${ }^{2}$, and Dirk Draheim ${ }^{3[0000-0003-3376-7489]}$ \\ 1 Department of Information Society Services Development \\ Ministry of Economics and Communication \\ Suur-Ameerika 1, 10122 Tallinn, Estonia \\ helena.korge@mkm.ee \\ 2 Software Science Department \\ Tallinn University of Technology \\ Akadeemia tee 15a, 12618 Tallinn, Estonia \\ regina.erlenheim@taltech.ee \\ 3 Information Systems Group \\ Tallinn University of Technology \\ Akadeemia tee 15a, 12618 Tallinn, Estonia \\ dirk.draheim@taltech.ee
}

\begin{abstract}
In the last decade, effectiveness, efficiency and quality have been main objectives in the transformation of government services. Citizen orientation can be seen as the crucial driver behind these objectives. A contemporary theme in all of this is about proactive services. Proactive services switch the service delivery from reactive to proactive, thereby, promising a yet unforeseen level of quality. In this paper, we ask how to successfully design proactive business event services in the Estonian company registration portal. We investigate current problems of this e-service as encountered by Estonian entrepreneurs. We conduct qualitative interviews with experts from the government and micro-business owners that use the registration portal. Based on the findings, we give a set of recommendations for designing proactive business event services in the public sector.
\end{abstract}

Keywords: e-government, proactive services, life events, service design

\section{Introduction}

All major life and business events, such as acquiring education, getting a job, starting a family, or starting a company, demand for interactions with the government via various separately developed services that are provided by different state agencies or local governments. Thus, the citizen needs to communicate with multiple authorities and needs to visit various web-portals to get things done. Due to the overall demand for government services to become more efficient and customer-oriented, countries with more advanced e-governments such 
as Estonia [1], New Zealand [2-4], and Taiwan [5-7] have started to look into providing proactive services based on and triggered by life and business events. A proactive service groups together several services related to the same life event or business event, so that, for the service user, they appear as a single service that ideally functions automatically or with a minimum of interaction.

Proactive services are a contemporary topic in e-government service provision. As early as in 2011, the e-Government Program of Taiwan 2011-2016 [5] contains proactive services as a strategic element:

"Proactive One-stop Service: We are simplifying service processes and integrating interagency services from a life cycle and overall service perspective, which let us provide the public with one-stop end-to-end government services." [5]

In Estonia, the notion of proactive service entered regulations. Since May 2017, it appears in regulation no. 88 (Principles for Managing Services and Governing Information) as follows:

"S2(3) Proactive services are the direct public services provided by an authority on its own initiative in accordance with the presumed will of persons and based on the data in the databases belonging to the state information system. Proactive services are provided automatically or with the consent of a person." [8]

Despite all of this, only a few studies exist on the subject; and theories on proactive services are emerging only recently. In this paper, we aim at determining the necessary requirements for successfully designing proactive business event services. Estonia strategically aims at developing proactive services, compare with $[8,1]$. One behalf of this, it is planned to renew the already existing company registration portal (CRP) by 2025. An objective of our research is to support the designers of the new CRP services, so that the new CRP would adhere better to the needs of the users. We claim that many of the findings are of general nature, so that they can be useful also for other countries that want to develop proactive services.

We target the following overall research question:

- How to design proactive business event services for the new Estonian company registration portal?

In service of the overall research question, we aim at answering the following auxiliary research questions:

- What requirements should proactive business event services meet?

- What features stakeholders expect from the future service?

For the purpose of this research, we have conducted in-depth semi-structured interviews with experts from the four public agencies that are involved as stakeholders in the renewal of the company registration portal, i.e., the Ministry of 
Finance (MoF), the Ministry of Economics and Communications (MoEC), the Ministry of Justice (MoJ), the Centre of Registers and Information Systems (CRIS) and, furthermore, with three owners of micro businesses who use the company registration portal.

We start with a discussion of related work in Sect. 2. In Sect. 3, we provide an overview of the Estonian company registration portal. In Sect. 4, we aim at answering the auxiliary research questions. In Sect. 5, we aim at answering the overall research question. We briefly discuss future research directions in Sect. 6 and finish with a conclusion in Sect. 7 .

\section{Related Work}

In the emerging notion of proactive service, two established concepts of e-government service design are amalgamated, i.e., the concept of life/business events and the concept of proactivity. Estonian regulations distinguish between proactive services and event services, where the concept of event service is used to gather certain aspects of proactive services, compare also with (2), as follows:

"\$2(4) Event services are the direct public services provided jointly by several authorities so that a person would be able to perform all the obligations and exercise all the rights conferred on the person due to an event or situation. An event service compiles several services (hereinafter component service) related to the same event into a single service for the user." [8]

Henceforth, we rather do not want to use the term event service and want to speak about proactive services only. However, we still want to talk about proactive business event services as opposed to proactive life event services. Also, our interviewees use the term event service.

Wimmer [9] and Wimmer and Tambours [10] explain life events or life episodes as an important service design metaphor that helps to increase citizen orientation of e-government services. The events in this metaphor include not only "human" life events but also business events that are also called business situations in $[9,10]$. The orientation towards life/business events is a convenient requirement elicitation tools for e-services, but not only; beyond that, it provides a metaphor for structuring e-services portals. Orientation towards life/business events is an essential ingredient of proactive service design [6,7,11-14].

In [15], Vintar and Leben report on the prototypical implementation of a lifeevent portal for the Republic of Slovenia. The quality of the Slovenian life-event portal has also been analyzed by Vintar et al. [16], compare also with [17].

The case study of e-government in Singapore [18] by Srivastava and Teo reveals that proactive provision of information is a main factor in increasing citizens' trust in e-government services.

For Dunleavy et al. [19] pro-activity is part of transcending new public management. Here, proactivity is about anticipating citizens' needs, e.g., "using feasible algorithms, agencies can then proactively try to match their services to meet citizens' needs or the key risks to policy" [19]. In [20], Linders identifies 
"proactive information dissemination" [20] as a key ingredient in moving from a stage of customer-to-government $(\mathrm{C} 2 \mathrm{G})$, or "citizen sourcing" [20], to a stage of government-to-customer, or "government as platform" [20].

Linders, Liao and Wang [6,7] explain that proactive services are about transforming e-service delivery from a pull to push model. They identify administrative effectiveness and efficiency, quality of e-services and, on behalf of this, quality of life for citizens as the objectives for introducing proactive services. They report on three cases of e-government initiatives in Taiwan: (i) the so-called e-housekeeper initiative, an integrated messaging platform of the government agencies, (ii) the proactive citizen hotline of the city of Taipei [21], and (iii) a pilot program in decreasing digital divide.

In $[11,12]$, Sirendi and Taveter conduct a concept study on proactive service design, including a prototypical implementation, for the family benefits system of the Estonian National Social Insurance Board. A main objective of the proactive service design in $[11,12]$ is user centricity as a key rationale of service design [2225]. In [13], Sirendi et al. analyze two concrete e-government services with respect to current shortcomings and their potential for proactive service design. The first is about providing services for parents of disabled children in the Estonian e-services portal ${ }^{4}$; the second is the Australian mobile web-application Ask Izzy ${ }^{5}$ that provides services and support for the homeless. On the basis of this analysis, guidelines for introducing proactive e-services are created.

Schuppan and Köhl [14] consider research in proactive services (proactive government) in [14], as relevant for meeting citizens' expectations towards egovernment services and e-government service portals.

\section{The Estonian Company Registration Portal}

Estonia is strong in providing public e-services for businesses. Almost everything can be done online - quick and easy - starting a business, declaring taxes, changing data etc. ${ }^{6}$ However, the provision of business services is decentralized and distributed over multiple agencies and portals. In order to fulfill all of their legal duties, business owners need to move between several platforms and registries, each with a different design and requirements. One of the most used platforms is the company registration portal of the Centre of Registers and Information Systems (CRIS), that provides a secure and convenient platform for entrepreneurs to start a business, submit documents and change information to the e-business register. The system holds information on all legal persons registered in Estonia. It allows private persons to start a company and legal persons to establish new enterprises. All Estonian citizens can log into the CRP with their ID-cards or mobile IDs and, soon, also with smart $\mathrm{IDs}^{7}$. The CRP is available since 2007;

\footnotetext{
${ }^{4}$ www.eesti.ee

${ }^{5}$ https://askizzy.org.au/

${ }^{6}$ https://e-estonia.com/

7 As of May 2019, there are around 127.600 active enterprises and 9.500 apartment associations in Estonia.
} 
but it is not required to use the CRP for starting a company, i.e., it is still possible to do this the conventional way via a notary; although, this is much more expensive and time- consuming (it takes around five days to set up a company instead of two hours). ${ }^{8}$

Figure 1 shows the current, rather simple process of establishing a private limited company - the most common type of business in Estonia. Upon entering the portal, the user needs to start an application for registering a new enterprise. He needs to specify its type (private limited company, sole proprietorship, limited partnership, general partnership, or non-profit). Then, the user needs to provide additional information such as the name of the business, its statute, persons involved, or the main area of activity. The application must be signed digitally, and state fee needs to be paid electronically. Upon that, an entry into the business register is made.

However, the overall process is not as simple as it appears on first sight and this deserves some remarks. In addition to the CRP registration, companies need to fulfill more obligations with respect to other agencies and portals such as registering in the e-taxation portal, getting a VAT number or registering their employees. If the area of business is subject to specific regulations as, e.g., in the construction industry or the food industry, a business need to submit also a notice or needs to apply for a license in the register of economic activities. Furthermore, registering a company in the CRP is only possible if all the persons that have been involved in its establishment (members of the management board, founders etc.) are able to digitally sign the establishing application and the respective documents - otherwise, the registration has to be done with the notary.

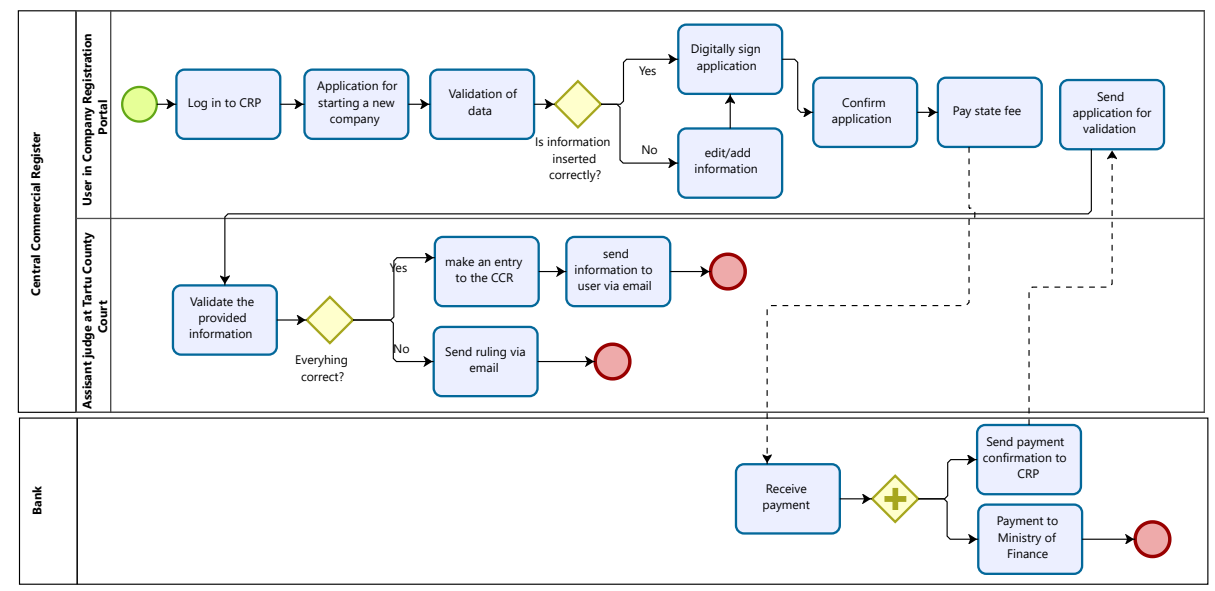

Fig. 1. As-is model of starting a company in the Estonian company registration portal.

\footnotetext{
${ }^{8}$ https://www.rik.ee/en/international/e-business-register
} 


\section{Results}

We have conducted in-depth semi-structured interviews with the Estonian deputy governmental CIO from the Ministry of Economics and Communications (MoEC), a project manager from the Ministry of Finance (MoF), an e-governance team leader from the Centre of Registers and Information Systems (CRIS), and a further expert from the Ministry of Justice (MoJ). Furthermore, we conducted three additional interviews with owners of micro businesses who use the CRP, in order to understand the needs and expectations of one of its main target groups. The interviews have been conducted in November 2018. All but one interview have been conducted one-on-one, face-to-face. One interview has been conducted via email. All interviews have been conducted in Estonian to simplify communication and to avoid translation errors. Afterwards, the interviews have been transcribed and translated.

We analyzed the interviews with respect to five areas: (i) the state of business service provision, (ii) the functionality of the CRP, (iii) event-based service provision, (iv) level of bureaucracy and (v) barriers to further improvements.

One of the main issues confirmed by all interviewees is that services are distributed over multiple agencies and platforms, which makes the service provision less user-friendly for entrepreneurs. The interviewee from the MoF claimed that, due to the many websites, entrepreneurs can easily get confused about where to find the desired information: "The main problem is that services are dispersed and that is not user-friendly. The entrepreneur has to orientate himself in different websites and sometimes does not even know where to go or does not know all his obligations."

A few interviewees brought out that the CRP works pretty well, but that it is old. The interviewee from the MoEC was rather critical and claimed that the portal is outdated: "It is not great - according to today's standards. It was built in 2008 or something. It is old and can become much better. But it is going to be great, they are moving towards it."

With respect to event-based logic, the interviewees seemed to have a good idea of what can be achieved with this. The interviewee from the CRIS explained how event-based service provision can help to offer personalized services: "The idea is that the environment is so clever that it can provide services that are important to that company. For example, I am interested in Harju county or enterprises with more than a million Euro turnover. With these indicators, we can provide a very personalized approach to utilizing all the information in order to gauge the best contact and relevance to the business."

Then, we asked the entrepreneurs about the level of bureaucracy. In general, the interviewees do not feel that the state asks too much information. At the same time, since proactive service provision has not been discussed widely, people generally do not know how things could be done differently. However, two interviewees mentioned that both of them have already forgotten some deadline, which indicates that the notification system could be improved.

With respect to barriers to the introduction of proactively, three project members mentioned the importance of data security. This indicates that it needs 
extra attention on that. One project member mentioned that a similar in the past project suffered organizational issues such as lack of clear communication. This should be kept in mind for any project that aims at introducing proactive services. The interviewee from the MoE stated: "The Data Protection Inspectorate (DPI) is the key player in creating event services. Things need to be talked through on how to do thing. Data protection must be in the focus."

Not all characteristics of good service design [22-25] have been implemented in the CRP. There is need for a change. However, the issues can be fixed by providing proactive event-based services. As a conclusion, we summarize benefits of implementing proactive business event in Table 1.

Table 1. Benefits of implementing proactive business event services.

\begin{tabular}{|c|c|}
\hline Benefit & Explanation \\
\hline $\begin{array}{l}\text { Improved business } \\
\text { environment }\end{array}$ & $\begin{array}{l}\text { Proactive and automated services allow entrepreneurs to focus } \\
\text { and to invest more time and effort into their core } \\
\text { competencies, i.e., freeing them from dealing with } \\
\text { administrative obligations. }\end{array}$ \\
\hline $\begin{array}{l}\text { Better user } \\
\text { experience }\end{array}$ & $\begin{array}{l}\text { A precondition of proactive event-based service provision is } \\
\text { better cooperation of state agencies and their information } \\
\text { systems. Better interoperability of state information systems } \\
{[26,27] \text { allows for designing a convenient one-stop-shop service. }}\end{array}$ \\
\hline $\begin{array}{l}\text { Once-only } \\
\text { principle }[28,29]\end{array}$ & $\begin{array}{l}\text { Duplication of data is reduced. Entrepreneurs do not have to } \\
\text { submit the same data several times, as cross-usage of data } \\
\text { increases. }\end{array}$ \\
\hline Better data quality & $\begin{array}{l}\text { Since state agencies automatically gather data from } \\
\text { companies, the change also increases the data quality. This } \\
\text { enables policy makers to make decisions based on more } \\
\text { accurate data. Anonymous data should be shared with them } \\
\text { as well, so that entrepreneurs can also benefit from this. }\end{array}$ \\
\hline $\begin{array}{l}\text { Increased awareness } \\
\text { of service provision }\end{array}$ & $\begin{array}{l}\text { Information and services can be found in a single place which } \\
\text { makes life easier for all associations. }\end{array}$ \\
\hline $\begin{array}{l}\text { Better overview of } \\
\text { companies }\end{array}$ & $\begin{array}{l}\text { Since all the information is in a single place, entrepreneurs } \\
\text { have a better overview of the current status of their company. }\end{array}$ \\
\hline
\end{tabular}

Table 1 lists the benefits of proactive services with respect to service quality. There might be some further, more indirect benefits on behalf of the improved service quality. First, the convenient and simple business environment could attract more people to become entrepreneurs. Second, it is advantageous for the reputation of Estonia: using an innovative approach such as proactive services is in line with Estonia's standing as a leading-edge IT-country. Furthermore, the resulting simpler business environment could attract foreign capital and more e-residents [30, 31]. 


\section{Recommendations}

When it comes to the introduction of proactive e-services, it is important that all stakeholders interact with each other throughout the project to gain a mutual understanding of their needs. For a proactive business event service, in order to be effective, a single sign-on authentication process should be used. Furthermore, the once-only principle (TOOP) [28, 29] should be followed. All technical aspects take considerable time; that is why it is recommended to tackle these issues early. At the same time, it is important to keep data security in mind, which plays a large role in creating interactive portals. It is advised to involve a data security officer early. The portal should have a scalable design so that new features can be easily integrated. Furthermore, it is advised to have a state-wide agreement that clarifies which services are grouped under which event. This enables easier communication between the involved state agencies and enables a clear schema for users. A similar agreement should be used for the triggering points of proactivity. With respect to this, is also advised to divide business services into three categories: (i) services that are provided automatically, (ii) services that allow for opting out, and (iii) services that require to opt in. If the state could divide all services into such categories in its regulations, the implementation of proactive services would become much smoother.

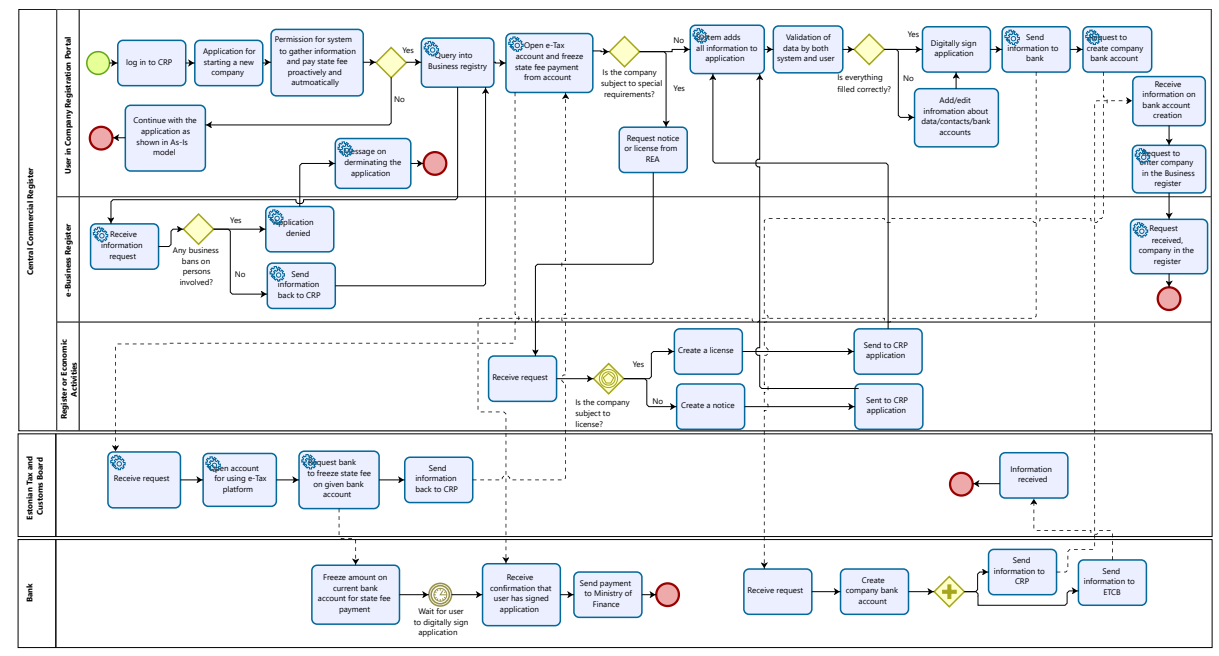

Fig. 2. To-be model for starting a company in the Estonian company registration portal.

Figure 2 proposes a to-be process model of starting a company in the CRP, compare also with the as-is process in Fig. 1. As the first step, the user needs to provide basic information (company name, area of activity etc.). Then, the system asks whether it may gather information from other state databases. If 
not, the user can proceed with the application as shown in the as-is process in Fig. 1. Such opt-out from proactive service provision is important - at least if the system is in its early phases. In case that a foreigner wants to start a company, such opt-out is essential. Otherwise, i.e., it the user agrees, the system queries multiple other databases and registries. The system checks whether any company stakeholders have any business bans. If not, the system automatically makes a request to the Estonian Tax and Customs Board's (ETCB) system to open an e-taxation account and freeze state fee payment from the bank account provided to the ETCB. The payment will not be made immediately, i.e., not before the user digitally signs the application. As the next step, the system checks whether the company operates in a field that is subject to special requirements and must be registered in the Register of Economic Activities (REA). If so, it provides a possibility for making the necessary amendments. The system moves on to a validation and, possibly, correction of the data. Then, the system asks the user to digitally sign. Then, the system sends a notification to the bank to unfreeze the state fee. Then, it sends another request to create a company bank account. After the company bank account is created, the system sends a request to the ebusiness register for entering a new company. Here, it is necessary to agree with the private sector, i.e., the banks, to keep the system as functional as possible.

\section{$6 \quad$ Future Directions}

Proactive services have been described as a paradigm shift from pull to push. A closer look reveals that this is a slightly odd metaphor. In established portals, the citizen pulls the service from the government, whereas, with proactive services, the government pushes the service to the citizen. But, in that narrative, a change of perspective happens, i.e., from the citizen to the government. If the story is told, consistently, from the citizen's perspective, the essence of the proactive service paradigm should be coined as from pull to pushed. Of course, from pull to pushed does not sound so nice any more. But that is exactly the point: What we see, based on previous experience [32], is, that we should care to consider the user not merely as a consumer/customer, but also as a citizen. There is a need for deep and discoursive [33] research of user adoption of proactive services. In user adoption studies it can easily happen that we are biased in favor of project success, i.e., we consider user concerns as critical for the project but sometimes stop in analyzing the concerns behind the concerns [34].

As a concrete next step in this direction, we will conduct a survey ${ }^{9}$ on the impact of digital initiatives. We are interested, in how much and in what respect digital transformation will impact our societies, governments, economies, and daily lives and work. Among other recent digital initiatives, we will ask this, in particular, with respect to proactive services, including emerging topics such as smart business processes [35-37] and automatic decision making (ranging from basic administrative tasks to automatic court case decisions).

\footnotetext{
${ }^{9}$ together with Capgemini Germany (Business \& Technology Solutions Public Sector), Mitshubishi UFJ (Research \& Consulting)
} 


\section{Conclusion}

In this paper, we investigated the current situation in business e-service provision in the Estonian company registration portal, in order to be able to understand the requirements for designing proactive business event services. The current situation shows direct negative factors such as a high level of bureaucracy and little user-centricity. Seven interviews with stakeholders have been conducted to learn about these issues, i.e., with four members of government authorities plus three micro business owners, who are considered as main beneficiaries of the system. The interviewees provided relevant feedback on stakeholders' needs and for requirements of future proactive services.

Life events are an established metaphor that helps to increase the citizen orientation of e-government services and portals. As such, they are not about triggering services. It can be said, that only with proactive services, life events become live. Proactivity is an established e-government best practice in the design of government information portals. Only with proactive services, proactivity is used transactional - beyond mere dissemination of information. Therefore, it can be said, that only with proactive services, proactivity becomes active.

Proactive services have been characterized as paradigm shift from pull to push, however, actually, from the citizens' perspective, it is a paradigm shift form pull to pushed. Therefore, further research is needed in user adoption of proactive services. This research needs to be deep and discoursive, in particular, we must take care that the user is not only considered as a consumer in such research, but also as a citizen.

\section{References}

1. Estonian Parliament: Interpellation on e-Government Developments 14.01.2019. http://stenogrammid.riigikogu.ee/et/201901141500\#PKP-24022.

2. State Services Comission - Te Kawa Mataaho: Better Public Services - Improving Interaction with Government, New Zealand (2017) http://www.ssc.govt.nz/bpsimproving-interaction-government.

3. State Services Comission - Te Kawa Mataaho: Service Innovation Work Programme, New Zealand (2019) https://www.digital.govt.nz/digitalgovernment/strategy/5-focus-areas-for-digital-change/service-innovation-workprogramme/.

4. State Services Comission - Te Kawa Mataaho: SmartStart a new type of service, New Zealand (2018) https://www.digital.govt.nz/showcase/smartstart-anew-type-of-service/.

5. National Development Council: E-Government Program of Taiwan: 2011-2016. National Development Council (2011)

6. Linders, D., Wang, C.M.: Proactive e-governance: Flipping the service delivery model in Taiwan. In: Proceedings of the 7th Intl. Conference on Theory and Practice of Electronic Governance. ICEGOV '13, ACM (2013) 154-157

7. Linders, D., Liao, C.Z.P., Wang, C.M.: Proactive e-governance: Flipping the service delivery model from pull to push in Taiwan. Government Information Quarterly 35(4, Supplement) (2018) $68-76$ 
8. Estonian Government: Principles for Managing Services and Governing Information, Regulation no. 88. Riigi Teataja - State Gazette (31.05.2017) https://www.riigiteataja.ee/en/eli/507072017004/.

9. Wimmer, M.A.: A European perspective towards online one-stop government: the eGOV project. Electronic Commerce Research and Applications 1(1) (2002) 92 103

10. Wimmer, A., Tambours, E.: Online one-stop government: A working framework and requirements. In Traunmüller, R., ed.: Information Systems - The e-Business Challenge. IFIP WCC TC8: IFIP World Computer Congress, TC 8, Springer (2002) $117-130$

11. Sirendi, R., Taveter, K.: Bringing service design thinking into the public sector to create proactive and user-friendly public services. In Nah, F.F.H., Tan, C.H., eds.: HCI in Business, Government, and Organizations: Information Systems, Springer (2016) 221-230

12. Sirendi, R.: Designing proactive public services as sociotechnical systems by using agent-oriented modelling. In: Proceedings of ECDG'2016 - the 16th European Conference on Digital Government, Academic Conferences and Publishing International (2016) 308-316

13. Sirendi, R., Mendoza, A., Barrier, M., Taveter, K., Sterling, L.: A conceptual framework for effective appropriation of proactive public e-services. In: Proceedings of ECDG'2018 - the 18th European Conference on Digital Government, Academic Conferences and Publishing International (2018) 213-221

14. Schuppan, T., Köhl, S.: One stop government: Stalled vision or a matter of design? empirical findings from social services in Germany. In: Proceedings of the 50th Hawaii Intl. Conf. on System Science, Association for Information Systems (2017) $2448-2457$

15. Vintar, M., Leben, A.: The concepts of an active life-event public portal. In: Proceedings of EGOV'2002 - the 1st Intl. Conf. on Electronic Government. Volume 2456 of LNCS., Springer (2002) 383-390

16. Vintar, M., Kunstelj, M., Leben, A.: Benchmarking the quality of Slovenian lifeevent portals. In Löffler, E., M.Vintar, eds.: Improving the Quality of East andWest European Public Services. Ashgate (2004) 208-221

17. Kunstelj, M., Vintar, M.: Evaluating the progress of e-government development: A critical analysis. Information Polity 9(3-4) (2004) 131-148

18. Srivastava, S., Teo, T.: Citizen trust development for e-government adoption: Case of Singapore. In: Proceedings of PACIS 2005 - the 9th Pacific Asia Conference on Information Systems, Association for Information Systems (2005) 721-734

19. Dunleavy, P., Margetts, H., Bastow, S., Tinkler, J.: New public management is dead - long live digital-era governance. Journal of Public Administration Research and Theory 16(3) (2005) 467-494

20. Linders, D.: From e-government to we-government: Defining a typology for citizen coproduction in the age of social media. Government Information Quarterly 29(4) (2012) 446-454

21. Chen, D.Y., Huang, T.Y., Hsiao, N.: Reinventing government through on-line citizen involvement in the developing world: A case study of Taipei city mayor's e-mail box in Taiwan. Public Administration and Development 26(5) (2006) 409423

22. Shostack, G.L.: How to design a service. European Journal of Marketing 16(1) (1982) 49-63

23. Shostack, G.L.: Designing services that deliver. Harvard Business Review 84115 (January-February 1984) 133-139 
24. Kimbell, L.: Designing for service as one way of designing services. International Journal of Design 5(2) (2011) 41-52.

25. Stickdorn, M., Schneider, J.: This is Service Design Thinking - Basics, Tools, Cases. Wiley (2012)

26. Kalja, A.: The first ten years of X-road. In Kastehein, K., ed.: Estonian Information Society Yearbook 2011/2012, Ministry of Economic Affairs and Communications of Estonia (2012) 78-80

27. Paide, K., Pappel, I., Vainsalu, H., Draheim, D.: On the systematic exploitation of the Estonian data exchange layer X-road for strengthening public private partnerships. In: Proceedings of ICEGOV'2018: the 11th Intl. Conf. on Theory and Practice of Electronic Governance, ACM (2018)

28. Wimmer, M., Marinov, B.: SCOOP4C: Reducing administrative burden for citizens through once-only - vision and challenges. Jusletter IT (February) (2017)

29. Wimmer, M., Tambouris, E., Krimmer, R., Gil-Garcia, J., Chatfield, A.: Once only principle: Benefits, barriers and next steps. In: Proceedings of DG.O 2017 - the 18th Annual Intl. Conf. on Digital Government Research, ACM (2017) 602-603

30. Tammpuu, P., Masso, A.: Transnational digital identity as an instrument for global digital citizenship: The case of Estonia's e-residency. Information Systems Frontiers (2019)

31. Kotka, T., Del Castillo, C., Korjus, K.: Estonian e-residency: Benefits, risk and lessons learned. In: Procseedings of EGOVIS'2016 - the 5th Intl. Conf. on Electronic Government and the Information Systems Perspective. Volume 9831 of LNCS. (2016) 3-15

32. Muldme, A., Pappel, I., Lauk, M., Draheim, D.: A survey on customer satisfaction in national electronic ID user support. In: Proceedings of ICEDEG'2018 - the 5th Intl. Conf. on eDemocracy \& eGovernment, IEEE (2018) 31-37

33. Habermas, J.: Moral Consciousness and Communicative Action. MIT Press (1991)

34. Schein, E.: Organizational Culture and Leadership. Wiley

35. Draheim, D.: Business Process Technology - A Unified View on Business Processes, Workflows and Enterprise Applications. Springer (2010)

36. Draheim, D.: Smart Business Process Management. In: 2011 BPM and Workflow Handbook. Workflow Management Coalition (2012) 207-223

37. Mendling, J., Baesens, B., Bernstein, A., Fellmann, M.: Challenges of smart business process management: An introduction to the special issue. Decision Support Systems 100 (2017) 1 - 5 Smart Business Process Management. 